\title{
TITLE:
}

\section{Principles to guide investment towards a stable climate}

\author{
AUTHORS: \\ Richard J. Millar ${ }^{1}$, Cameron Hepburn²,3,4, John Beddington ${ }^{4}$, Myles R. Allen ${ }^{1,4,5}$ \\ ${ }^{1}$ Environmental Change Institute, University of Oxford, Oxford, UK. \\ ${ }^{2}$ Institute for New Economic Thinking, Oxford Martin School, Oxford, UK. \\ ${ }^{3}$ Smith School of Enterprise and the Environment, University of Oxford, Oxford, UK. \\ ${ }^{4}$ Oxford Martin School, University of Oxford, Oxford, UK. \\ ${ }^{5}$ Department of Physics, University of Oxford, Oxford, UK.
}

CORRESPONDING AUTHOR:

Correspondence to: Richard J. Millar (richard.millar@ouce.ox.ac.uk)

Investors will play a major role, whether active or passive, in climate change mitigation. To enable prudent decision-making, we propose three physically-based engagement principles that could be used to assess whether an investment is consistent with a long-term climate goal.

Apartheid in South Africa gave investors moral headaches in the 1970s. Should they continue to invest in South Africa or should they divest, sending a signal about the illegitimacy of the apartheid regime? In response to this conundrum, a set of simple principles was advanced in 1977. The Sullivan Principles provided guidelines for investment in morally acceptable companies. ${ }^{1}$ Investors complying with the guidance did not reduce returns - if anything returns were higher ${ }^{2}-$ and the Principles served as an important symbolic gesture against the legitimacy of the Apartheid government.

Climate change is creating similar moral headaches today. Should investors continue to invest in fossil fuels or should they divest, sending a signal about the perceived illegitimacy of particular business models in a changing climate? Further, given the internationally agreed aspiration towards achieving net zero emissions in the second half of the century, ${ }^{3}$ how should investors manage the legal and financial risks of this transition $?^{4}$ Investment principles such as the Sullivan Principles, and those outlined in this paper, can be useful if they help inform stakeholders at many levels, both serving as a corporate code of conduct for companies themselves, and providing investment guidance for asset managers and owners. For principles to have value in helping drive the transitions needed to stabilize climate they must do more than notionally acknowledge climate as a concern; they must have a demonstrable impact on corporate decision making.

The highly unequal distributions of both impacts from climate change, and of contributions to observed warming, make climate change a moral issue. This has led to an increased focus on the role of the financial sector in either sustaining the status quo or aiding the transition to a net-zero carbon world. Investors, asset managers and companies can easily get lost and frustrated in the maze of standards and disclosure criteria proliferating around the climate issue. A modern climate-specific 
set of principles is needed to provide investors with a minimal set of clear, fact-based guidance for climate-conscious investment which can be implemented by investors across the economy. While science alone cannot decide moral questions, a sound basis in scientific reality is a necessary starting point $^{5}$. There are myriad scientific facts relevant to socially responsible investment in fossil fuels, but two are of the utmost importance:

1. Net emissions of $\mathrm{CO}_{2}$ must fall to zero for temperatures to stabilise. ${ }^{6}$ Reaching zero net emissions is necessary to stabilise temperatures at any level, be it 2,3 or $4^{\circ} \mathrm{C}$ above preindustrial, to avoid ever-increasing climate impacts.

2. Achieving the goals of the Paris Agreement requires that net emissions must be zero well before temperatures exceed $2^{\circ} \mathrm{C}$. The cumulative impact of $\mathrm{CO}_{2}$ emissions on temperatures ${ }^{7}$ means that no further $\mathrm{CO}_{2}$ may be emitted into the atmosphere (without offsetting $\mathrm{CO}_{2}$ removal) after human-induced warming reaches the agreed limit: "well below $2^{\circ} \mathrm{C}$ above pre-industrial levels and pursuing efforts to limit the temperature increase to $1.5^{\circ} \mathrm{C}^{\prime \prime}$.

These facts have direct relevance to current investments. If emissions continue under a "businessas-usual" scenario, human-induced warming may exceed $1.5^{\circ} \mathrm{C}$ within two decades. ${ }^{8}$ Such a timeframe is well within the investment horizons of long lived emitting infrastructure assets. As coal fired-power stations have historically had a median lifetime of 37 years or more, ${ }^{9}$ a proposed plant, reaching financial close in 2018 and commencing operation in 2020, could be expected to run until almost 2060. Without compensating (and still largely hypothetical) measures to remove $\mathrm{CO}_{2}$ from the atmosphere, such infrastructure developments are likely to be inconsistent with the Paris Agreement. As such, the existing global pipeline of $570 \mathrm{GW}$ of new coal-fired power stations ${ }^{10}$ should be treated with great scepticism without a detailed, credible and investable plan for carbon capture or $\mathrm{CO}_{2}$ removal.

Corporate business plans can be tested against specific emissions scenarios, but such detailed comparisons are only credible over much shorter timescales, such as out to 2030 . Even then, ambitious mitigation scenarios are very sensitive to specific assumptions in the early decades. The achievement of short-term targets, such as $2 \%$ year-on-year emission reductions, does not necessarily imply that a company is on track to reach a long-term target of net zero emissions. As an alternative to detailed and potentially misleading comparison of business plans with specific emissions scenarios, we propose three simple principles to help guide investors, whether in the fossil fuel industry or other sectors.

1. Commitment to net zero emissions. All industries must eventually reach net zero emissions, even if some industries do so before others. Companies should commit to a date (or a temperature increase, such as $1.5^{\circ} \mathrm{C}$ or "well below $2^{\circ} \mathrm{C}^{\text {") }}$ ) before which the net $\mathrm{CO}_{2}$ emissions associated with their activities (including both supply chains and products sold) will be zero.

2. A profitable net zero emission business model. Company executives should have business plans that ensure the profitability of their business, and limit supply chain risks, once emissions reach net zero.

3. Quantitative mid-term targets. Mid-term targets (e.g. 2030) that are directly relevant to achieving a net-zero business model, such as the rate and long-term trajectory of reductions in $\mathrm{CO}_{2}$ emissions, are vital to properly assess compatibility with the Paris Agreement. For example, global temperatures are projected by the IPCC $5^{\text {th }}$ Assessment Report to reach around $1.2^{\circ} \mathrm{C}$ above pre-industrial ${ }^{11}$ by about 2030 . By this level of warming, emissions scenarios approximately consistent with the $1.5^{\circ} \mathrm{C}$ goal and commencing serious mitigation 
in the present decade have reduced global $\mathrm{CO}_{2}$ emissions by at least $40 \%$ relative to business-as-usual (BaU), or at least $20 \%$ below BaU for the $2^{\circ} \mathrm{C}$ goal. These rates of emissions reduction could act as useful benchmarks against which company progress could be measured.

Ambitious commitments to achieving net-zero emissions (Principle 1) by individual companies will be essential to bring about the net-zero global emissions that are needed to limit warming to the long-term goal of the Paris Agreement. For these commitments to be plausible, it is essential that the company can convince investors that in doing so it would remain profitable (Principle 2) and offers a mechanism for external verification of its progress to net-zero (Principle 3 ). These three overarching, scientifically-grounded principles follow directly from the two key facts above, and can be applied in investment criteria for firms across the economy, helping investors understand longterm risks of climate change in capital allocation decisions.

Committing to net zero emissions by $2^{\circ} \mathrm{C}$, "well below $2^{\circ} \mathrm{C}$ ", or even $1.5^{\circ} \mathrm{C}$, has implications for capital decisions today. Near-term reductions in corporate emissions by, say, 2-3\% per annum are of little value if, at the same time, long-lived investments in fossil infrastructure make it economically irrational to meet the net zero emissions target required by Principle 1. Investors should be focussing on the allocation of current and future capital expenditure and research and development into carbon-neutral or carbon-negative processes or products, to assess whether the company satisfies Principle 2. For instance, if the company proposes to reach its target through CDR, how will this be achieved, paid for, monitored and permanently maintained?

Some companies will find it straightforward to meet these criteria. Indeed, some may already meet them by the nature of their business activity. Others will find it more difficult, including in core industrial process such as steel or cement, and greater flexibility in mid-term targets under Principle 3 may be appropriate for such sectors. However, it remains true that all companies must now tackle challenging questions regarding future profitability in a world with net-zero emissions, and if flexibility is exploited to postpone decisions, it may harm profitability in the long term.

To illustrate the operation of the principles in practice, we apply them to three large listed companies: BHP Billiton, a miner; Unilever, a consumer goods company, and Statkraft, a utility (Box 1). These case studies demonstrate that compliance with the principles is possible. The widespread adoption of the three principles would provide new and valuable information: complementing existing disclosure regimes on climate change governance, strategy, risk management and metrics to incorporate the core scientific requirement of net zero emissions.

Box 1: Case studies illustrating the principles applied to three large companies

BHP Billiton is a miner and a large extractor of fossil fuels. ${ }^{12}$ Whilst BHP's current business model creates a flow of $\mathrm{CO}_{2}$ emissions into the atmosphere, a pathway to compliance with the principles is not far out of reach. First, the company acknowledges that global net emissions need to fall to zero by the second half of the century. ${ }^{13}$ It also has a longer-term goal to reach net-zero operational emissions in the second half of the century ${ }^{14}$ making important steps towards satisfying Principle 1 (strategies to address the emissions from the use of their product would also be required for full compliance). Regarding Principle 2, the company is investing in carbon capture and sequestration development projects and the company supports carbon pricing, and argues that its core mining activities aside from fossil fuel extraction (e.g. copper) are potentially more profitable in a net zero emissions world. However, it also notes upsides from Paris for gas, and continued demand for oil in a transition to a $2^{\circ} \mathrm{C}$ world, that, while possibly significant in the medium term, are difficult to reconcile with a net-zero emissions target. Finally, it has a target of reducing absolute operational 
emissions in the 2022 financial year below the 2017 financial year baseline (after overachieving a similar target for 2017 relative to 2006). This is a start, but it leaves the company without any midterm performance metric on the path to net zero emissions needed to achieve Principle 3 . While BHP Billiton currently strictly fails to meet these criteria, it may have a path to doing so in the future.

Unilever has climate-policies that extend across the entire value-chain of their products. They have a clear target to halve the life-cycle emissions of their products by or before 2030, and have a strategy for net-zero emissions from their operations by the same date ${ }^{15}$, representing substantial progress towards meeting Principle 1 . While the company is currently struggling to reduce the lifecycle emissions of its products (so currently falls short on Principle 2), this measurable and well-defined mid-term target is an important step towards a full net-zero emissions plan, and represents an important commitment to take responsibility for the full climate impact of their business model, satisfying Principle 3 with targets, that, if achieved, would be compatible with a $1.5^{\circ} \mathrm{C}$ pathway. To achieve their mid-term target, Unilever needs first to reverse the $8 \%$ increase in the lifecycle greenhouse gas impact of their products since 2010.

Statkraft is primarily a renewable energy company, and it is therefore naturally aligned to the goals of the Paris agreement, satisfying Principle 2. In 2016, it currently sources over $96 \%$ of its generation from renewables, ${ }^{16}$ however Statkraft also owns and operates a small number of state-of-the-art gas power plants in markets with a high share of coal power production. The gas power plants operated many more hours in 2016 than in 2015 due to price movements, implying higher emissions for Statkraft itself. Since 2007 the company has not developed any new gas generation capacity. To be fully compliant with our criteria to achieve Principles 1 and 3, Statkraft would need to develop a clear and measurable plan to run down and retire their existing gas share (or they could, in principle, choose to invest in carbon capture) whilst limiting the cumulative emissions arising from it, and already has a target to only grow in renewable energy ${ }^{17}$.

The principles advanced in this paper are as simple as possible, while remaining true to the underlying climate science. They offer a simple scientific lens through which to view the myriad of disclosure criteria and rankings of corporate climate ambition. They require the development of a clear long-term plan to net zero emissions, with interim milestones and metrics, as a necessary addition to existing climate disclosures. If this perspective could reduce the lock-in of high-carbon capital that will subsequently need to be stranded, it will yield both economic and climate dividends. An early indication of usefulness is that a working version of the principles ${ }^{18}$ has already been applied to companies on the stock exchange of one country. ${ }^{19}$

Given the increasing interest in forward-looking climate change related disclosures, ${ }^{20}$ the time is now right for the long-term constraints implied by science to be employed by the financial community in examining investments. In particular, our hope is that funds, institutional investors and endowments under pressure to divest from fossil fuels, choose to act - whether for moral or financial reasons with sound science behind them.

\section{Acknowledgments:}

RJM, CH and MRA would like to acknowledge financial support through the Oxford Martin Net Zero Carbon Investment Initiative. We would like to acknowledge valuable comments and feedback from Ella Adlen and Ryan Rafaty. We are grateful to the participants of two workshops held in mid-2015, the first chaired by Sir Martin Smith at the Oxford Martin School and the second by Professor Dan Schrag at Harvard University's Centre for the Environment, which helped inform much of our thinking when developing an early version of these principles. 


\section{References}

${ }^{1}$ Sethi, S. P. \& Williams, O. F. Business and Society Review 105, 169-200, (2000).
2 Lashgari, M. K. \& Gant, D. R. Review of Social Economy 47, 74-83 (1989).
${ }^{3}$ UNFCCC, Paris Agreement (2015). Accessed at: http://unfccc.int/paris_agreement/items/9485.php
${ }^{4}$ Covington, H., Thornton, J. \& Hepburn, C. Nature 530, 156 (2016).
${ }^{5}$ Science Based Targets Initiative. Sectorial Decarbonization Approach (SDA): A method for setting corporate
emission reduction targets in line with climate science. (2015). Accessed at http://sciencebasedtargets.org/SDA/

${ }^{6}$ Matthews, H. D. \& Caldeira, K. Geophysical Research Letters 34, L04705 (2008).

${ }^{7}$ Matthews, H. D. \& Solomon, S. Science 340, 438-439 (2013).

8 Henley, B. J. \& King, A. D. Geophysical Research Letters 44, 4256-4262 (2017).

${ }^{9}$ Davis, S. J. \& Socolow, R. H. Environmental Research Letters 9, 084018 (2014).

${ }^{10}$ Shearer, C., Ghio, N., Myllyvirta, L., Yu, A. \& Nace, T. Boom and bust: Tracking the global coal plant pipeline. CoalSwarm, Greenpeace USA, Sierra Club, (2017).

${ }^{11}$ Kirtman, B. et al, Near-term Climate Change: Projections and Predictability, Ch. 11 of Climate Change 2013: The Physical Science Basis. Contribution of Working Group I to the Fifth Assessment Report of the Intergovernmental Panel on Climate Change (2013).

${ }^{12}$ BHP Billiton: http://www.bhpbilliton.com/environment/climate-change

${ }^{13}$ BHP Billiton: http://www.bhpbilliton.com//media/bhp/documents/investors/reports/2016/bhpbillitonclimatechangeporfolioanalysis2016.pdf?la=en ${ }^{14}$ BHP Billiton: Sustainability Report 2017. Accessed at http://www.bhp.com//media/documents/investors/annual-reports/2017/bhpsustainabilityreport2017.pdf? ${ }^{15}$ Unilever, https://www.unilever.com/sustainable-living/the-sustainable-living-plan/reducing-environmentalimpact/greenhouse-gases/

${ }^{16}$ Statkraft, Corporate Responsibility Report 2016. Accessed at: http://www.statkraft.com/globalassets/xannual-report-2016/arsberetning/cr-engelsk-rapport-010317.pdf

${ }^{17}$ Statkraft: https://www.statkraft.com/about-statkraft/corporate-responsibility/climate/

${ }^{18}$ Oxford Martin School Net Zero Carbon Investment Initiative, Working Principles for Investment in Fossil Fuels. Accessed at: http://www.oxfordmartin.ox.ac.uk/publications/view/2073

${ }^{19}$ Australian Market Forces: Business as Usual: Australian Companies Not Planning for Climate Change. Accessed at: http://superswitch.org.au/wp-content/uploads/2016/12/Oxford-Martin-Assessment-Business-asUsual.pdf

${ }^{20}$ Task Force on Climate-related Financial Disclosures, Recommendations of the Task Force on Climate-related Financial Disclosures. Accessed at: https://www.fsb-tcfd.org/publications/recommendations-report/ 